\title{
DESINFESTAÇÃO SUPERFICIAL DE EXPLANTES ISOLADOS DE RAMOS SEMILENHOSOS E HERBÁCEOS DE Eugenia involucrata DC. (MYRTACEAE)
}

\author{
Diego Pascoal Golle ${ }^{1}$, Lia Rejane Silveira Reiniger ${ }^{2}$, Rogério Antônio Bellé3 ${ }^{3}$ Aline Ritter Curti ${ }^{4}$
}

(recebido: 10 de setembro de 2010; aceito: 28 de setembro de 2012)

\begin{abstract}
RESUMO: No presente trabalho, objetivou-se comparar duas metodologias de desinfestação superficial de explantes isolados de ramos semilenhosos e herbáceos de Eugenia involucrata DC. (Myrtaceae), visando à obtenção de cultivos assépticos. O melhor controle da contaminação bacteriana nos segmentos nodais provenientes de ramos semilenhosos foi obtido pela imersão, durante 25 minutos, em hipoclorito de sódio a 1,5\%. Entretanto, 39,35\% dos explantes apresentaram colônias bacterianas e o excesso de contaminações inviabilizou os cultivos. Segmentos apicais caulinares e segmentos nodais oriundos de ramos herbáceos não diferiram entre si e apresentaram reduzidas contaminações fúngicas $(13,75 \%)$ e bacterianas $(0,41 \%)$, além de elevado estabelecimento $(91,92 \%)$. Hipoclorito de sódio a 1,5\%, nos tempos testados, não é eficiente em promover a desinfestação superficial de segmentos nodais que já possuam aspectos lenhosos. É possível a obtenção de culturas assépticas de E. involucrata pelo cultivo de segmentos apicais caulinares e nodais obtidos após a realização de poda, e desinfestados com o auxílio de bicloreto de mercúrio e de hipoclorito de sódio.
\end{abstract}

Palavras-chave: Biotecnologia florestal, cultura de tecidos, espécie nativa.

\section{SUPERFICIAL DISINFESTATION OF ISOLATED EXPLANTS FROM SEMI-HARDWOOD AND HERBACEOUS BRANCHES OF Eugenia involucrate DC. (MYRTACEAE)}

\begin{abstract}
This study aimed to compare two methods of surface disinfestation of explants isolated from semi-hardwood and herbaceous branches of Eugenia involucrata DC. (Myrtaceae) to obtain aseptic cultures. The better control of bacterial contamination in nodal segments from semi-hardwood branches was obtained by immersion for 25 minutes in sodium hypochloride at $1.5 \%$. However, $39.35 \%$ of explants showed bacterial colonies and excessive contamination made it impossible the cultures. Apical and nodal shoot segments derived from herbaceous branches did not differ and showed reduced fungal contamination (13.75\%) and bacterial contamination $(0.41 \%)$, and high in vitro establishment $(91.92 \%)$. Sodium hypochlorite at $1.5 \%$ in the time tested is not efficient in promoting surface disinfestation of nodal segments that already present woody aspects. It is possible to obtain aseptic cultures of E. involucrata for growing shoot apical and nodal segments obtained after the pruning, and sterilized with the aid of mercuric chloride and sodium hypochlorite.
\end{abstract}

Key words: Forestry biotechnology, tissue culture, native species.

\section{INTRODUÇÃO}

A cerejeira-do-rio-grande (Eugenia involucrata DC.) é uma espécie arbórea da família Myrtaceae de ocorrência natural no Rio Grande do Sul, em outros estados brasileiros e, também, em alguns países da América do Sul. Embora apresente um enorme potencial para integrar sistemas produtivos, ainda é pouco utilizada com essa finalidade. Além de sua importância ecológica, uma vez que é espécie dispersada pela fauna e adequada à recuperação de áreas degradadas, apresenta interesse paisagístico. Na silvicultura, destacam-se a excelente qualidade e a durabilidade natural de sua madeira. Oferece, adicionalmente, recursos não madeiráveis, a partir de sua utilização na área frutícola e, na literatura, são observados relatos acerca de suas propriedades medicinais (RODRIGUES; CARVALHO, 2001).

Entretanto, a cerejeira-do-rio-grande apresenta dificuldades na propagação, o que representa um obstáculo ao seu aproveitamento econômico. Suas sementes são recalcitrantes e não mantêm o potencial germinativo durante o armazenamento, tornando-se inviáveis já nas

\footnotetext{
${ }^{1}$ Biólogo, Professor Doutor em Engenharia Florestal - Universidade de Cruz Alta/UNICRUZ - Centro de Ciências da Saúde - Laboratório de Cultura de Tecidos Vegetais "in vitro" - 98020-290 - Cruz Alta, RS, Brasil - diego.golle@ gmail.com

${ }^{2}$ Engenheira Agrônoma, Professor Doutora em Ciência e Tecnologia de Sementes - Universidade Federal de Santa Maria/UFSM Departamento de Fitotecnia - Núcleo de Biotecnologia e Melhoramento - 97105-900 - Santa Maria, RS, Brasil liarejanesilveirareiniger@yahoo.com.br

${ }^{3}$ Engenheiro Agrônomo, Professor Doutor em Biologie et Physiologie Végétales - Universidade Federal de Santa Maria/UFSM Departamento de Fitotecnia - 97105-900 - Santa Maria, RS, Brasil - belle@smail.ufsm.br

${ }^{4}$ Engenheira Florestal, Doutoranda em Engenharia Florestal - Universidade Federal de Santa Maria/UFSM - Departamento de Fitotecnia Núcleo de Biotecnologia e Melhoramento - 97105-900 - Santa Maria, RS, Brasil - alinerittercurti@yahoo.com.br
} 
primeiras semanas após a coleta (CARVALHO, 2008). Estudos sobre modalidades de propagação da espécie são incipientes. Face ao exposto, técnicas de cultura de tecidos poderiam auxiliar na produção de mudas, possibilitando, também, a seleção de genótipos com características superiores.

A propagação vegetativa via cultura de tecidos pode agilizar o melhoramento genético de espécies lenhosas, dados os longos ciclos de vida necessários para atingirem a idade reprodutiva, o que dificulta a avaliação de progênies (PARANJOTHY et al., 1990). Além disso, a cultura de tecidos pode auxiliar na conservação in vitro de germoplasma dessas espécies (FERREIRA et al., 1998). A propagação in vitro está entre as técnicas da biotecnologia vegetal com maior interesse científico e econômico, sendo a técnica de micropropagação a mais difundida entre as espécies florestais e com aplicações comprovadas nesse setor (XAVIER et al., 2007).

Uma das principais dificuldades encontradas na produção de mudas de espécies florestais pela micropropagação, além do enraizamento, é a obtenção de um número suficiente de culturas assépticas que permitam dar prosseguimento ao cultivo in vitro. Isso se verifica em função da frequente presença de microrganismos associados aos explantes e da relativa ineficiência dos procedimentos de desinfestação superficial que costumam ser empregados com sucesso em espécies herbáceas.

No presente trabalho, objetivou-se comparar duas metodologias de desinfestação superficial de explantes semilenhosos e herbáceos isolados de plantas de $E$. involucrata DC., mantidas em casa de vegetação, visando à obtenção de culturas assépticas.

\section{MATERIAL E MÉTODOS}

\subsection{Período e local de realização dos experimentos}

Os experimentos foram realizados de março a dezembro de 2008, no Núcleo de Biotecnologia e Melhoramento do Departamento de Fitotecnia da Universidade Federal de Santa Maria (UFSM), localizada em Santa Maria, Rio Grande do Sul, Brasil.

\subsection{Desinfestação superficial de explantes isolados de ramos semilenhosos de Eugenia involucrata DC.}

Como doadores de explantes foram utilizados espécimes de E. involucrata com aproximadamente dois anos de idade, mantidos em casa de vegetação. As plantas foram cultivadas em vasos plásticos $(22 \mathrm{~cm}$ de altura e $24 \mathrm{~cm}$ de diâmetro; capacidade 8 L) contendo o substrato Plantmax ${ }^{\circledR}$.
Além de irrigações diárias, as plantas receberam, mensalmente, $400 \mathrm{~mL}$ de solução de nitrogênio, fósforo e potássio (5-20-20) a $1 \mathrm{~g} \mathrm{~L}^{-1}$ e, a cada 15 dias, $400 \mathrm{~mL}$ de solução a $1 \mathrm{~g} \mathrm{~L}^{-1}$ de nitrogênio (uréia). Foram realizadas pulverizações quinzenais com solução à base de Cercobin700PM ${ }^{\circledR}$ (Thiophanato Metílico) a $1 \mathrm{~g} \mathrm{~L}^{-1}$ e Sulfato de Estreptomicina a $0,1 \mathrm{~g} \mathrm{~L}^{-1}$, visando a efetuar uma pré-desinfestação. Essa mesma solução também foi pulverizada no substrato.

Como explantes, foram utilizados segmentos nodais de ramos de aspecto semilenhoso com, aproximadamente, $15 \mathrm{~cm}$ de comprimento e apresentando quatro a cinco segmentos. A fim de homogeneizar os explantes, foram excluídos os segmentos apical e basal dos ramos. Logo após o isolamento dos ramos, os segmentos nodais foram imersos em água destilada, contendo $1 \mathrm{~g} \mathrm{~L}^{-1}$ do fungicida Benlate $500^{\circledR}$ (Benomyl) e $0,1 \mathrm{~g} \mathrm{~L}^{-1}$ de Sulfato de Estreptomicina. No laboratório, os explantes foram lavados com o auxílio de água corrente, esponja e detergente comercial, e, após, seccionados os segmentos, os quais permaneceram imersos em água destilada até a desinfestação.

Em câmara de fluxo laminar, os explantes foram expostos, por 30 segundos, a uma solução de etanol a $70 \%$ (v/v), seguindo-se um enxágue com água esterilizada. Posteriormente, os explantes foram imersos em solução de hipoclorito de sódio $(\mathrm{NaOCl})$ a $1,5 \%(\mathrm{v} / \mathrm{v})$ contendo três gotas de detergente comercial, obtida a partir de um estoque concentrado a $10 \%$, permanecendo sob agitação por 0,5 , 10, 15, 20 ou 25 minutos. A seguir, foi realizado um triplo enxágue e os explantes foram mantidos em água esterilizada durante o procedimento de inoculação no meio de cultura.

A unidade experimental foi composta por um frasco (capacidade para $150 \mathrm{~mL}$ ) contendo $30 \mathrm{~mL}$ de meio nutritivo e três explantes. O meio utilizado foi o MS (MURASHIGE; SKOOG, 1962) acrescido de $30 \mathrm{~g} \mathrm{~L}^{-1}$ de sacarose, $0,1 \mathrm{~g} \mathrm{~L}^{-1}$ de mio-inositol e $7 \mathrm{~g} \mathrm{~L}^{-1}$ de ágar. $\mathrm{O}$ experimento foi conduzido em delineamento inteiramente casualizado, com 10 repetições, em um total de 60 parcelas e 180 explantes.

Para a introdução in vitro, realizou-se a remoção dos resquícios foliares existentes e, também, seccionaram-se os segmentos a $0,3 \mathrm{~cm}$ acima da região nodal e $0,8 \mathrm{~cm}$ abaixo desta. O corte da parte basal foi realizado em bisel, visando a aumentar a superfície de contato com o meio nutritivo e facilitar a introdução. Cada explante possuía duas gemas dormentes.

\subsection{Desinfestação superficial de explantes isolados de} ramos herbáceos de Eugenia involucrata DC.

Neste experimento, as plantas doadoras de explantes apresentavam cerca de três anos de idade e

Cerne, Lavras, v. 19, n. 1, p. 77-82, jan./mar. 2013 
permaneceram em casa de vegetação, inicialmente, sob as mesmas condições descritas no experimento anterior. No entanto, quatro semanas precedentes à coleta dos explantes, realizou-se uma poda em toda a parte aérea das plantas. As podas foram realizadas, deixando-se regiões de galhos e ramos com duas ou mais gemas visíveis.

Após a poda, os tratos culturais foram efetuados como descrito anteriormente, contudo, foi intensificado o uso da solução de nitrogênio (uréia), à qual foi adicionado potássio, na proporção 2:1, efetuando-se aplicações semanais. Além disso, os tratos sanitários foram administrados a cada sete dias, encharcando-se os ramos por completo.

Para a coleta dos explantes, foram escolhidos ramos jovens, verdes, possuindo entre dois e três segmentos, considerando-se o apical e o(s) nodal(is). Os segmentos foram imersos em solução, contendo Benlate $500^{\circledR}$ (Benomyl) a $1 \mathrm{~g} \mathrm{~L}^{-1}$ e Sulfato de Estreptomicina a $0,1 \mathrm{~g} \mathrm{~L}^{-1}$ durante 30 minutos. No laboratório, os segmentos foram cuidadosamente lavados em água corrente, com o auxílio de esponja e detergente comercial e, na sequência, seccionados com o uso de tesoura. Após, permaneceram por 30 minutos em solução de etanol a $70 \%$ (v/v), seguindose um enxágue em água esterilizada. A seguir, em capela de exaustão, os explantes foram imersos em solução de bicloreto de mercúrio $\left(\mathrm{HgCl}_{2}\right)$ a $0,05 \%(\mathrm{p} / \mathrm{v})$, por 10 minutos. Posteriormente, foram enxaguados com água esterilizada e, em câmara de fluxo laminar, foram expostos à agitação por 15 minutos em solução de $\mathrm{NaOCl}$ a $1,5 \%$ (v/v) acrescida de três gotas de detergente comercial. Decorrido esse período, as plantas foram enxaguadas três vezes e permaneceram, durante a inoculação, em água esterilizada contendo $100 \mathrm{mg} \mathrm{L}^{-1}$ de ácido ascórbico. Os explantes foram compostos por segmentos apicais (região apical dos ramos), seccionados em bisel a $0,8 \mathrm{~cm}$ do nó e contendo uma gema dormente; e segmentos nodais, os quais tiveram seus pares de folhas laterais retirados, deixando-se apenas o vestígio inicial do limbo, e cortados a $0,3 \mathrm{~cm}$ acima e 0,8 $\mathrm{cm}$ abaixo da região do nó, a qual possuía duas gemas dormentes. O corte da região basal foi realizado em bisel.

$\mathrm{O}$ experimento foi conduzido em delineamento inteiramente casualizado, em esquema fatorial $2 \times 3$, relacionados aos dois tipos de explantes (segmentos apicais e segmentos nodais) e aos três meios nutritivos testados: MS (MURASHIGE; SKOOG, 1962), 1/2 MS (composto pela diluição do meio MS à metade de sua concentração de sais) e WPM - Wood Plant Medium (LLOYD; MCCOWN, 1981). O ensaio apresentou 10 repetições, cada uma composta por um frasco (capacidade para $150 \mathrm{~mL}$ ) contendo $30 \mathrm{~mL}$ de meio nutritivo e dois explantes, contabilizando 60 unidades experimentais e 120 explantes inoculados. Aos meios de cultura foram acrescidos $30 \mathrm{~g} \mathrm{~L}^{-1}$ de sacarose, $0,1 \mathrm{~g} \mathrm{~L}^{-1}$ de mio-inositol e $7 \mathrm{~g} \mathrm{~L}^{-1}$ de ágar.

Durante os primeiros 30 dias de cultivo, os explantes permaneceram nos meios nutritivos citados, aos quais foram acrescidos $1 \mu \mathrm{M}$ de Ácido alfa-Naftalenoacético (ANA) e 5 $\mu \mathrm{M}$ de Thidiazuron (TDZ). Após esse período, os explantes foram subcultivados por mais 30 dias nos respectivos meios nutritivos, porém, na ausência de reguladores de crescimento e com o acréscimo de $1 \mathrm{~g} \mathrm{~L}^{-1}$ de carvão ativado.

\subsection{Datas das avaliações e variáveis avaliadas}

Noprimeiro experimento, as avaliações foram efetuadas aos 21 dias de cultivo e, no segundo, aos 60 dias. Foram avaliadas: contaminação bacteriana (presença de colônias bacterianas junto aos explantes); contaminação fúngica (contaminações compostas por micélios fúngicos junto aos explantes); contaminação geral (contaminantes junto aos explantes, independentemente do microrganismo causador); e oxidação fenólica (escurecimento dos explantes); todas expressas em porcentagem. Adicionalmente, avaliou-se o estabelecimento in vitro dos explantes, mas no primeiro experimento não foi efetuada análise estatística desta variável, por razões explicitadas nos respectivos resultados.

\subsection{Condições de cultivo e análises estatísticas}

Em ambos os experimentos, para a vedação dos frascos foi utilizado papel alumínio. $\mathrm{O} \mathrm{pH}$ dos meios foi ajustado para 5,8 antes da inclusão do ágar e após a adição dos reguladores de crescimento ou carvão ativado, de acordo com o tratamento. Os meios de cultura foram autoclavados por 20 minutos a $121^{\circ} \mathrm{Ce} 1,5 \mathrm{~atm}$ de pressão.

As unidades experimentais foram dispostas em sala de cultivo com temperatura controlada de $25 \pm 3^{\circ} \mathrm{C}$, fotoperíodo de 16 horas e intensidade luminosa de 20 $\mu \mathrm{mol} \mathrm{m} \mathrm{m}^{-2} \mathrm{~s}^{-1}$, obtida por meio de lâmpadas fluorescentes brancas frias tipo luz do dia.

Após testar a normalidade dos dados por meio do teste de Kolmogorov-Smirnov e a homogeneidade de variâncias pelo teste de Bartlett, foram realizadas transformações pela função $\sqrt{x+0,5}$ seguido das análises de variância. Quando o valor de " $F$ " foi significativo, dados de tratamentos quantitativos foram submetidos à análise de regressão polinomial e aqueles de tratamentos qualitativos, à comparação de médias por meio do teste de Tukey a 5\% de probabilidade de erro. Os resultados apresentados são as médias originais obtidas e os modelos matemáticos também

Cerne, Lavras, v. 19, n. 1, p. 77-82, jan./mar. 2013 
apresentam os valores não transformados. O programa estatístico SISVAR (FERREIRA, 2000) foi utilizado para o processamento dos dados.

\section{RESULTADOS E DISCUSSÃO}

3.1 Desinfestação superficial de explantes isolados de ramos semilenhosos de Eugenia involucrata DC.

Não houve diferenças significativas entre os períodos de imersão dos explantes na solução de hipoclorito de sódio a 1,5\% para a contaminação fúngica ( $\mathrm{P}=0,2421)$, a contaminação geral $(\mathrm{P}=0,0627)$ e a oxidação fenólica $(\mathrm{P}=0,6291)$. Foram observadas diferenças apenas para a contaminação bacteriana $(\mathrm{P}=0,0126)$.

O padrão de resposta dos segmentos nodais aos tratamentos para a presença de bactérias ajustou-se a um modelo de regressão linear decrescente (Figura 1), em que, com o aumento dos tempos de contato dos explantes com o hipoclorito de sódio, houve uma redução significativa na contaminação. O melhor tratamento foi a imersão dos segmentos nodais por 25 minutos no desinfestante, resultando em 39,35\% de explantes apresentando colônias bacterianas.

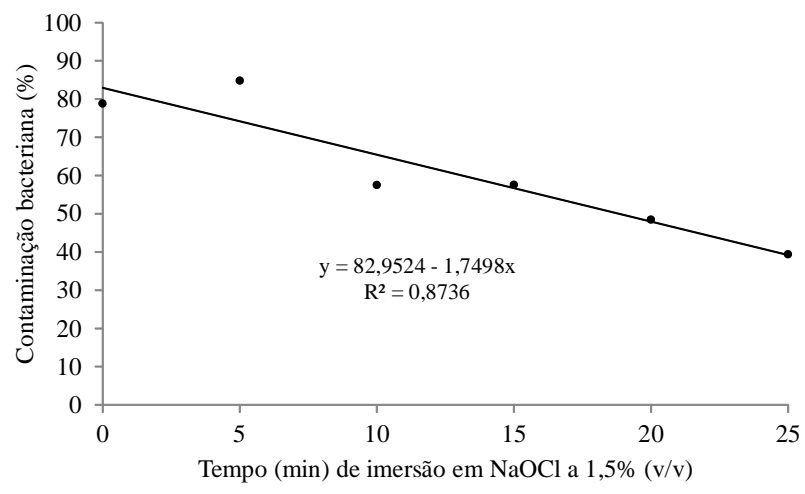

Figura 1 - Efeito dos diferentes tempos de imersão de segmentos nodais de Eugenia involucrata em solução de hipoclorito de sódio $(\mathrm{NaOCl})$ a 1,5\% (v/v) sobre a contaminação bacteriana aos 21 dias de cultivo in vitro. Santa Maria, RS, UFSM, 2010.

Figure 1 - Effect of different times of soaking of nodal segments of Eugenia involucrata in 1.5\% sodium hypochloride solution $(\mathrm{NaOCl})$ on the bacterial contamination at 21 days of in vitro culture. Santa Maria, RS, UFSM, 2010.

Foi observada alta contaminação geral (média de $67,14 \%$ ), e reduzida contaminação fúngica $(7,06 \%)$. Isso demonstra que os tratamentos de desinfestação não foram eficientes em controlar a presença de bactérias nos cultivos, sugerindo a necessidade de procedimentos adicionais para a obtenção de cultivos assépticos.

Contaminações são obstáculos à cultura de tecidos de espécies lenhosas, merecendo atenção especial. Em Pongamia pinnata L. Pierre, uma árvore da família das leguminosas, o estabelecimento in vitro foi limitado pelas contaminações microbianas, sendo possível estabelecer culturas assépticas apenas com o uso de Plant preservative mixture (PPM) e Cefotaxima (SUJATHA; HAZRA, 2007).

Com maiores tempos de contato dos tecidos de Eugenia involucrata com o hipoclorito de sódio, houve a ocorrência de injúrias nos explantes. Isso sugere que o aumento na concentração do desinfestante ou nos períodos de imersão, visando a melhorar a eficiência da desinfestação, deve ser avaliado. Essas injúrias refletiram na oxidação fenólica $(57,55 \%)$, possivelmente como resposta celular ao estresse causado, já que ferimentos estimulam a atividade da enzima fenilalanina amonialiase (PAL), relacionada à formação de compostos fenólicos (TAIZ; ZEIGER, 2004).

O tipo de explante inoculado (segmento nodal semilenhoso) favoreceu a oxidação por reagir mais ativamente com o hipoclorito de sódio. Como alternativa, optou-se pelo uso (no experimento subsequente) de explantes mais jovens obtidos por meio de podas, os quais teriam menor contaminação e, pelo menor tempo de contato com o ambiente, talvez possibilitassem, também, a redução de contaminantes.

$\mathrm{Na}$ lenhosa Ulmus minor Mill., o cultivo de brotações diretamente extraídas das plantas no campo resultou em contaminações muito elevadas, próximas a $100 \%$. Contudo, com o emprego de ramos com brotos dormentes, mantidos em casa de vegetação, as contaminações reduziram-se em 90\% (CONDE et al., 2008). É importante destacar que, no presente estudo, muitos contaminantes apareceram após algumas semanas de cultivo, o que indica a possível presença de microrganismos endofíticos.

Observou-se o estabelecimento de todos os explantes que não apresentaram oxidação fenólica e, até mesmo de explantes que, inicialmente, não tinham contaminações presentes. Contudo, com o decorrer do experimento, o aumento nas contaminações de origem endógena inviabilizou os cultivos, permitindo inferir que ramos lenhosos não constituem na fonte de explantes mais adequada para o cultivo.

Cerne, Lavras, v. 19, n. 1, p. 77-82, jan./mar. 2013 


\subsection{Desinfestação superficial de explantes isolados de ramos herbáceos de Eugenia involucrata DC.}

Os resultados das contaminações bacterianas e fúngicas evidenciaram a eficiência do processo de desinfestação utilizado, possivelmente pela otimização dos tratos sanitários durante o desenvolvimento das brotações jovens, pelo menor tempo de contato com os agentes contaminantes, bem como pela inclusão do bicloreto de mercúrio durante a assepsia.

Não houve interação $(\mathrm{P}=0,3718)$, influência do tipo de explante $(\mathrm{P}=0,3218)$ e nem do meio nutritivo utilizado $(\mathrm{P}=0,3746)$ sobre a presença de bactérias junto aos cultivos $(0,41 \%)$. No que diz respeito aos fungos $(13,75 \%)$, observou-se o mesmo comportamento, com os valores de "P", respectivamente, de 0,1730; 0,3144; e 0,5616. Deve-se ressaltar que valores elevados de contaminação são comuns para espécies lenhosas, uma vez que é difícil a obtenção de cultivos in vitro totalmente assépticos a partir de material com origem ex vitro nos primeiros cultivos (XAVIER et al., 2007). Contudo, a presença de microrganismos implica no descarte das culturas contaminadas, reduzindo a produtividade do trabalho e aumentando os custos de produção das mudas.

Já, em relação à contaminação geral, os explantes apresentaram aos 30 dias diferenças $(\mathrm{P}=0,0421)$, com os segmentos apicais caulinares evidenciando uma menor contaminação geral $(6,66 \%)$ comparados aos segmentos nodais $(19,16 \%)$. Isso demonstra que tecidos mais jovens e menos lenhosos, além de estarem menos tempo em contato com o ambiente, dificilmente apresentam contaminações endógenas.

Os resultados obtidos são similares aos que vêm sendo observados em diversas espécies perenes, nas quais o bicloreto de mercúrio revelou-se muito eficiente. Shirin e Rana (2007) regeneraram in vitro Bambusa galucescens (Willd.) Siebold ex Holttum desinfestando explantes nodais pela imersão em solução de bicloreto de mercúrio a $1 \%$ por 10 minutos; já, em Holarrhena antidysenterica (L.) Wall., uma espécie arbórea com propriedades medicinais, a desinfestação com este agente, em uma concentração mais reduzida $(0,1 \%)$, em contato com os explantes por apenas 2 minutos, apresentou bom desempenho (MALLIKARJUNA; RAJENDRUDU, 2007).

A oxidação fenólica, avaliada aos 60 dias, também apresentou diferenças $(\mathrm{P}=0,0028)$ apenas para o tipo de explante. Segmentos nodais jovens apresentaram reduzida oxidação $(15,74 \%)$, diferindo daquela observada em segmentos apicais caulinares $(38,33 \%)$, em que, provavelmente, houve um aumento nas injúrias durante o processo de desinfestação, especialmente em função da fragilidade dos tecidos. Essas injúrias, ampliaram a ocorrência de oxidações no decorrer do tempo, possivelmente pelas mesmas razões citadas no experimento anterior.

Não houve interação $(\mathrm{P}=0,8375)$ e nem diferenças para o tipo de explante $(0,0790)$ e o meio de cultura $(0,5266)$ no que se refere ao estabelecimento in vitro das plantas. Observou-se uma média geral de estabelecimento de $91,92 \%$, embora com o decorrer do tempo, algumas contaminações tenham interferido no desenvolvimento das plantas. Para segmentos apicais caulinares, essa média foi de $87,77 \%$, enquanto para segmentos nodais foi de $96,06 \%$.

Na maioria das vezes, a presença de contaminações ou de aspectos oxidativos nos explantes, embora indesejados, não inviabilizaram o estabelecimento e o desenvolvimento in vitro das culturas.

\section{CONCLUSÕES}

O uso de segmentos apicais caulinares e de segmentos nodais oriundos de ramos herbáceos permite a obtenção de cultivos assépticos de E. involucrata e elevado estabelecimento in vitro. Para tanto, devem ser realizadas podas para a obtenção de ramos jovens, bem como tratamentos fisiológicos e sanitários intensivos nas plantas matrizes. Na desinfestação, além do uso do hipoclorito de sódio $(\mathrm{NaOCl})$ a 1,5\% (v/v) durante 15 minutos, deve ser realizada uma etapa prévia com bicloreto de mercúrio $\left(\mathrm{HgCl}_{2}\right)$ a $0,05 \%(\mathrm{p} / \mathrm{v})$ por 10 minutos.

\section{REFERÊNCIAS}

CARVALHO, P. E. Espécies arbóreas brasileiras. Brasília: EMBRAPA Informação Tecnológicas; Colombo: EMBRAPA Florestas, 2008. v. 3, 593 p.

CONDE, P.; SOUSA, A.; COSTA, A.; SANTOS, C. A protocol for Ulmus minor Mill. micropropagation and acclimatization. Plant Cell, Tissue and Organ Culture, Dordrecht, v. 92, n. 1, p. 113-119, Jan. 2008.

FERREIRA, D. F. Análises estatísticas por meio do Sisvar para Windows versão 4.0. In: REUNIÃO ANUAL DA REGIÃO BRASILEIRA DA SOCIEDADE INTERNACIONAL DE BIOMETRIA, 45., 2000, São Carlos. Anais... São Carlos: UFSCar, 2000. p. 255-258.

Cerne, Lavras, v. 19, n. 1, p. 77-82, jan./mar. 2013 
FERREIRA, M. E.; CALDAS, L. S.; PEREIRA, E. A. Aplicações da cultura de tecidos no melhoramento genético de plantas. In: TORRES, A. C.; CALDAS, L. S.; BUSO, J. A. (Ed.). Cultura de tecidos e transformação genética de plantas. Brasília: EMBRAPA-CNPH, 1998. p. 21-43.

LLOYD, G.; MCCOWN, B. Commercially feasible micropropagation of mountains laurel, Kalmia latifolia by use of shoot tip culture. Combined Proceedings International Plant Propagators Society, Washington, v. 30, p. 327-421, 1981.

MALLIKARJUNA, K.; RAJENDRUDU, G. High frequency in vitro propagation of Holarrhena antidysenterica from nodal buds of mature tree. Biologia Plantarum, Prague, v. 51, n. 3, p. 525-529, 2007.

MURASHIGE, T.; SKOOG, F. A revised medium for rapid growth and bio assays with tobacco tissue cultures.

Physiologia Plantarum, Copenhagen, v. 15, p. 473-497, 1962.

PARANJOTHY, K.; SAXENA, S.; BANERJEE, M.; JAIWAL, V. S.; BHOJWANI, S. S. Clonal multiplication of woody perennials. In: BHOJWANI, S. S. (Ed.). Plant tissue culture: applications and limitations. Amsterdam: Elsevier, 1990. p. 190-219.

RODRIGUES, V. E. G; CARVALHO, D. A. Levantamento etnobotânico de plantas medicinais no domínio do cerrado na região do alto rio grande, Minas Gerais. Ciência e

Agrotecnologia, Lavras, v. 25, n. 1, p. 102-123, jan./fev. 2001.

SHIRIN, F.; RANA, P. K. In vitro plantlet regeneration from nodal explants of field-grown callus in Bambusa glaucescens Willd. Plant Biotechnology Reports, Tokyo, v. 1, n. 3, p. 141-147, Aug. 2007.

SUJATHA, K.; HAZRA, S. Micropropagation of mature Pongamia pinnata Pierre. In Vitro Cellular and Developmental Biology-Plant, Columbia, v. 43, n. 6, p. 607-613, Dec. 2007.

TAIZ, L.; ZEIGER, E. Fisiologia vegetal. Porto Alegre: Artmed, 2004. 719 p.

XAVIER, A.; OTONI, W. C.; PENCHEL, R. M.

Micropropagação e enxertia in vitro de espécies florestais. In: BORÉM, A. (Ed.). Biotecnologia florestal. Viçosa, MG: UFV, 2007. p. 55-74. 